\title{
Circulating Dihydrotestosterone May Not Reflect Peripheral Formation
}

\author{
V. Toscano and R. Horton \\ Section of Endocrinology, Department of Medicine, University of Southern California, Los Angeles, California 90033
}

\begin{abstract}
We compared the blood $\left(\mathbf{P}_{\mathrm{B}}{ }^{\mathrm{DHT}}\right)$ and urine $\left(\mathrm{P}_{\mathrm{U}}{ }^{\mathrm{DHT}}\right)$ production rate of dihydrotestosterone (DHT) in normal men and women to determine whether peripheral formation was totally reflected in blood. $\mathbf{P}_{\mathbf{B}}{ }^{\mathrm{DHT}}$ was similar when measured at both sites in men (674 \pm 79 vs. $788 \pm 207 \mathrm{SE} \mu \mathrm{g} / \mathrm{d})$; however, $P_{U}{ }^{\text {DHT }}$ was greater than $P_{B}{ }^{D H T}$ in women $(174 \pm 55$ vs. $55 \pm 8 \mu \mathrm{g} / \mathrm{d}, P<0.02)$. Excretion rates of DHT and $3 \alpha$-androstanediol ( $3 \alpha$ diol) were similar in both sexes despite major differences in blood levels. However, between sexes large differences were present in $3 \alpha$ diol glucuronide (3adiolG) in both plasma and urine. These observations indicate that peripheral (renal) formation of DHT and probably $3 \alpha$ diol were not accurately determined by measurement of these steroids in blood. The large difference between blood and urine production rates in women suggests an important role of nontestosterone precursors of $5 \alpha$-reduced steroids. Measurements of $3 \alpha$ diolG may provide more insight into these peripheral events.
\end{abstract}

\section{Introduction}

Dihydrotestosterone (DHT), ${ }^{1}$ the $5 \alpha$-reduced metabolite of testosterone, is the mediator of androgen action and the nuclear androgen, especially in sexual tissues $(1,2)$. In peripheral tissue, DHT can be further metabolized to the androstanediols, $3 \alpha$ or $3 \beta,(3-5)$ and to $3 \alpha$-androstanediol glucuronide ( $3 \alpha$ diolG) (68). Previous studies have shown that DHT, $3 \alpha$-androstanediol (3 $\alpha$ diol), and $3 \alpha$ diolG arise from extrasplanchnic sites $(9,10)$, and direct secretion has also been excluded (11). It was hoped that plasma DHT might be an accurate reflection of peripheral formation; however, most observations do not support this. Plasma DHT is normal or only slightly increased in most hirsute and acne patients $(7,12,13)$, whereas other in vitro studies of hair follicles or sebaceous gland tissues in hirsutism indicate marked conversion activity of testosterone, androstenedione, and other precursors to DHT $(14,15)$. In men with $5 \alpha$-reductase

Dr. V. Toscano was a visiting scientist from the Instituto V Clinica Medica-Policlinico Umberto 1. Univ. La Sapienza, Rome, Italy.

Address all correspondence to Dr. R. Horton, Chief Endocrinology, University of Southern California, 2025 Zonal Avenue, Los Angeles, CA 90033. 1987.

Received for publication 29 July 1986 and in revised form 5 February

1. Abbreviations used in this paper: DHT, dihydrotestosterone; $3 \alpha$ diol, $3 \alpha$-androstanediol; $3 \alpha$ diolG, $3 \alpha$ diol glucuronide; $3 \beta$ diol, $3 \beta$-androstanediol; MCR, metabolic clearance rate; $\mathrm{MCR}^{\mathrm{DHT}}$, MCR of DHT; $\mathrm{P}_{\mathrm{B}}{ }^{\mathrm{DHT}}$, blood production rate of DHT; $\mathrm{P}_{\mathrm{U}}{ }^{\mathrm{DHT}}$, urine production rate of DHT.

J. Clin. Invest.

(c) The American Society for Clinical Investigation, Inc.

0021-9738/87/06/1653/06 \$1.00

Volume 79, June 1987, 1653-1658 deficiency that involves both peripheral and hepatic enzyme deficiency, blood levels of DHT can be normal in parallel with testosterone levels $(16,17)$.

In a recent study of $3 \alpha$ diolG kinetics, the calculated blood production rate of $3 \alpha$ diolG was three to four times higher than simultaneous blood production rate of DHT $\left(\mathrm{P}_{\mathrm{B}}{ }^{\mathrm{DHT}}\right)$ (18). $3 \alpha$ diolG is thought to be a marker of DHT formation. Mahoudeau et al., while evaluating the origin of blood DHT and its conversion to the androstanediols, concluded that most peripheral DHT formed is probably further metabolized before entering the general circulation (3). On the basis of this indirect evidence, we designed a study to determine more directly whether total body (peripheral) DHT formation exceeds that entering the circulation.

Our study finds a large difference between the specific activity and calculated production rates of DHT in blood and urine in women, which suggests that only a fraction of DHT synthesized by target tissues enters the circulation.

\section{Methods}

\section{Steroids}

$1,2\left[{ }^{3} \mathrm{H}\right] \mathrm{DHT}\left(55 \mathrm{Ci} / \mathrm{mM}\right.$ sp act), $4\left[{ }^{14} \mathrm{C}\right] \mathrm{DHT}$ (57 Ci/mM sp act), and $1,2\left[{ }^{3} \mathrm{H}\right] 3 \alpha \operatorname{diol}(30.1 \mathrm{Ci} / \mathrm{mM}$ sp act) from New England Nuclear, Boston, MA were purified as previously described $(19) .\left[{ }^{14} \mathrm{C}\right]$ Androstanediol was produced by treating $\left[{ }^{14} \mathrm{C}\right] \mathrm{DHT}$ with $3 \alpha$-hydroxysteroid dehydrogenase (Sigma Chemical Co., St. Louis, MO) in phosphate buffer and NADH for $20 \mathrm{~min}$. The steroid product was purified by repetitive chromatography steps to constant ${ }^{14} \mathrm{C} /{ }^{3} \mathrm{H}$-ratios.

\section{Infusion study on subjects}

The protocol was approved by our institutional research committee. Nine normal volunteers (four males and five females) were studied at our Clinical Research Center, and blood and urine samples were obtained under strict supervision (Table I). Subjects were infused through a forearm vein while supine with $50 \mu \mathrm{Ci}$ of $\left[{ }^{3} \mathrm{H}\right] \mathrm{DHT}$ in $5 \mathrm{ml}$ ethanol diluted to $100 \mathrm{ml}$ with sterile isotonic saline as previously described (19). A priming dose of $3-4 \mu \mathrm{Ci}$ was given at the beginning of the infusion from 8 to 9 a.m. and the infusion continued for $8 \mathrm{~h}$. Normal women were studied in the early follicular phase. Blood was obtained from the opposite arm at 6 and $8 \mathrm{~h}$ and urine was collected for three successive days and frozen.

\section{Steroid concentrations and diurnal variation}

Plasma DHT was measured on the day before the infusion from 8 to 9 a.m. and 5 to 6 p.m. In one male and female patient, blood was also collected six times every $4 \mathrm{~h}$ to evaluate circadian variation. Urine was collected on the day before the radioactive infusion and in two subjects, on two separate days to evaluate day to day variation of androgen excretion rates.

\section{Measurement of steroids}

Plasma DHT and $3 \alpha$ diol were measured after ether extraction and celite chromatography by radioimmunoassay (RIA) methods previously described and validated $(4,10,12) .15 \mathrm{ml}$ urine DHT and $3 \alpha$ diol (unconjugated) from a 24-h collection were measured with internal standard for correction of losses. The unconjugated steroid was extracted with ether (three times for $3 \mathrm{vol}$ ). The steroids were then purified in the same 
Table I. Clinical Data

\begin{tabular}{clll}
\hline & Age & Weight & Body surface \\
\hline & $y r$ & $k g$ & $m^{2}$ \\
Male & & & \\
1 & 23 & 60.1 & 1.73 \\
2 & 24 & 84.5 & 2.07 \\
3 & 39 & 123.3 & 2.6 \\
4 & 23 & 79.5 & 2 \\
Female & & & \\
1 & 29 & 50.8 & 1.54 \\
2 & 23 & 51.3 & 1.49 \\
3 & 31 & 61.4 & 1.6 \\
4 & 51 & 88 & 1.94 \\
5 & 34 & 64 & 1.63 \\
\end{tabular}

way as the plasma by using celite chromatography, which resulted in $70 \%$ overall recovery. Characteristics of the $3 \alpha$ diol and $3 \alpha$ diolG (e.g., sensitivity and precision) assays were similar when using either blood or urine $(4,10)$. Completeness of urine collection was monitored by creatinine excretion.

Each plasma and urine sample was measured in duplicate and the values reported represent the mean obtained in two or three different RIA runs. To minimize errors, the RIA evaluation of both plasma and urine samples were performed by using the same standard curve, and the amount transferred to RIA tubes was calculated on the basis of previous curve results so that plasma and urine results were read on the same part of the standard curve.

\section{Validation of the DHT assay in urine}

The characteristics of this assay used for urine analysis is fully described since comparison of blood and urine DHT was central to the study.

Specificity. The antibodies used (DHT antibodies obtained against $15 \beta$-carboxyethylmercapto-5 DHT-bovine serum albumin and the $3 \alpha$ diol antibody, against $3 \alpha$ diol-succinate-bovine thyroblobulin) on urine extracts were the same used for plasma and were purchased from Radioassay System Laboratories, Carson, CA. Further paper chromatography did not significantly alter the values obtained by the standard method.

Sensitivity. Sensitivity of the standard curves based on mean \pm 2 SD of intercept is $6 \pm 3 \mathrm{pg}$ for DHT and method blank values are $3.2 \pm 1.1$ $\mathrm{pg} /$ tube for DHT. The intra-assay and interassay coefficient of variation were 2 and $8.5 \%$, respectively.

Accuracy. A test of parallalism for DHT in urine was performed with increasing urine amounts $(7.5,15$, and $30 \mathrm{ml})$. A good correlation was obtained $(y=1.13 \times-0.82, r=0.9980, P<0.001)$.

\section{Purification of steroids after infusion of $\left[{ }^{3} \mathrm{H}\right] \mathrm{DHT}$}

Unconjugated steroids with ${ }^{14} \mathrm{C}$ indicator were extracted with ether (three times for $3 \mathrm{vol}$ ). After the hydrolysis step with $\beta$-glucuronidase (20), both the plasma and urine steroids together with the original steroid extract were handled identically using celite chromatography followed by a Bush A paper chromatography that separated the three $\mathrm{C} 19$ steroids from all other steroids, including $3 \beta$-androstanediol ( $3 \beta$ diol). Previous studies have demonstrated that these steps achieve radiochemical purity $(5,19)$. However, further proof of purity of both assays was demonstrated by the constancy of the ${ }^{14} \mathrm{C} /{ }^{3} \mathrm{H}$ ratio $(2.45$ vs. 2.45 for DHT and 1.07 vs. 1.10 for $3 \alpha$ diolG) between the two-step procedure and an additional paper chromatography. In separate studies, using $9,11\left[{ }^{3} \mathrm{H}\right] 3 \alpha$ diolG, we demonstrated that degradation did not occur during collection or storage of samples.

In all studies, counting times (three times for $50 \mathrm{~min}$ ) were chosen to produce errors of $<5 \%$.
Evidence for attainment of a steady state of labeled steroids In previous studies we have demonstrated that labeled, unconjugated $\left[{ }^{3} \mathrm{H}\right] \mathrm{C} 19$ steroids, such as DHT given by infusion, reach a state of equilibrium in subjects by $1.5-2 \mathrm{~h}$ if preceded by a loading dose $(4,5)$. Similarly, after DHT infusion, the level of radioactive $3 \alpha$ diolG in plasma reaches a steady state by $4-5 \mathrm{~h}(19)$. Sampling times were designed to exceed this, and differences in 6- and 8-h samples were $<10 \%$ without any trend.

\section{Calculations}

Plasma. The metabolic clearance rate (MCR) was determined by analysis of steady state $\left[{ }^{3} \mathrm{H}\right] \mathrm{DHT}$ levels according to the formula: MCR (liters/ day $)=(\mathrm{cpm}$ DHT infused per day $) /(\mathrm{cpm}$ DHT per liter $) .\left(\mathrm{P}_{\mathrm{B}}{ }^{\mathrm{DHT}}\right)$ was calculated as the product of the DHT averaged concentrations (nanograms per liter) for a.m. and p.m. samples and it's $\mathrm{MCR}\left(\mathrm{MCR}^{\mathrm{DHT}}\right)$ (liters per day). The specific activity of each steroid was calculated by dividing the cpm per liter at steady state by the mean plasma levels (nanograms per liter) and expressed as cpm per nanogram.

Urine. The urinary production rate of DHT $\left(\mathrm{P}_{\mathrm{U}}{ }^{\mathrm{DHT}}\right)$ was estimated as the reciprocal of the integrated DHT specific activity from $2 \mathrm{~d}$ of collected urines (i.e., cpm infused plus loading dose divided by cpm per nanogram of DHT).

Statistics. Wilcoxon signed rank test, both one and two-tailed, was utilized using Clinfo facilities, University of Southern California, Los Angeles, CA.

\section{Results}

The clinical data for all study patients are noted (Table I).

Plasma. Infusion rates of $\left[{ }^{3} \mathrm{H}\right] \mathrm{DHT}$, and concentrations of $\left[{ }^{3} \mathrm{H}\right] \mathrm{DHT}, 3 \alpha \mathrm{diol}$, and $3 \alpha \mathrm{diolG}$ as well as the concentration of nonlabeled androgens (nanograms per deciliter) previously measured in plasma as well as $\left[{ }^{3} \mathrm{H}\right] \mathrm{DHT}$ levels (cpm per liter) at 6 and $8 \mathrm{~h}$ of both male and female subjects are presented in Table II and Fig. 1. Also, the calculated $\mathbf{M C R}^{\mathrm{DHT}}$ and $\mathbf{P}_{\mathrm{B}}{ }^{\mathrm{DHT}}$ and specific activities of DHT, $3 \alpha$ diol, and $3 \alpha$ diolG are shown. The levels of $\left[{ }^{3} \mathrm{H}\right] \mathrm{DHT}$ were very similar at 6 and $8 \mathrm{~h}$ $(80,299 \pm 26,599$ vs. $84,776 \pm 25,096$ and $252,300 \pm 87,868$ vs. $240,750 \pm 83,140)$. Individual subjects demonstrated a slight circadian variation of unlabeled steroids, but values differed $<20 \%$.

$\mathrm{MCR}^{\mathrm{DHT}}$ based on 8-h infusions was $1,306 \pm 166$ liters/d in four men and $520 \pm 96$ liters/d in five women. The calculated $P_{B}{ }^{\text {DHT }}$ were $674 \pm 79 \mu \mathrm{g} / \mathrm{d}$ and $55 \pm 7 \mu \mathrm{g} / \mathrm{d}$ in men and women, respectively. The specific activity was much higher in women despite similar infusion doses and it fell progressively from DHT to $3 \alpha$ diol and $3 \alpha$ diolG in both men and women.

Urine. Most $\left[{ }^{3} \mathrm{H}\right] \mathrm{DHT}(84.6 \pm 3.8 \%)$ infused appeared in the first urine collection day with only a small amount $(15.4 \pm 3.8 \%)$ on the second and $<1 \%$ on the third day. Similar results were seen with $\left[{ }^{3} \mathrm{H}\right] 3 \alpha$ diol and $\left[{ }^{3} \mathrm{H}\right] 3 \alpha$ diolG. Even a larger fraction of $\left[{ }^{3} \mathrm{H}\right] 3 \alpha$ diolG was excreted on the first day $(93.5 \pm 1.6 \%)$, whereas the remainder appeared in the second urine collection. Excretion rates for 1 and $2 \mathrm{~d}$ were determined along with specific activity from combined day 1 and 2 pools to account for $>95 \%$ of excreted counts.

Table III gives the 8-h infusion rate plus the loading dose that must be used in calculating urinary production rates. Values

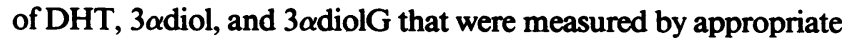
RIA techniques are also shown as well as the calculated specific activities and production rates (Fig. 2). Urinary DHT and $3 \alpha$ diol were $115 \pm 23$ and $204 \pm 27 \mathrm{ng} / \mathrm{d}$ in men and $75 \pm 33$ and $152 \pm 89$ $\mathrm{ng} / \mathrm{d}$ in women. Minor differences $(<10 \%)$ of day to day excretion rates of the three androgens were noted. 


\begin{tabular}{|c|c|c|c|c|c|c|c|c|c|c|c|c|}
\hline & \multirow{2}{*}{$\begin{array}{l}\text { DHT infusion } \\
(\mathrm{cpm} / 8 \mathrm{~h} \\
\left.\times 10^{-6}\right)\end{array}$} & \multirow[b]{2}{*}{ DHT } & \multirow[b]{2}{*}{ 3adiol } & \multirow[b]{2}{*}{ 3adiolG } & \multicolumn{4}{|l|}{ DHT } & \multicolumn{3}{|c|}{ Specific activity } & \multirow[b]{2}{*}{$\mathbf{P}_{\mathrm{B}}^{\mathrm{DHT}}$} \\
\hline & & & & & $6 \mathrm{~h}$ & $8 \mathrm{~h}$ & MCR & MCR & DHT & $3 \alpha$ diol & $3 \alpha$ diolG & \\
\hline & & $n g / d l$ & $n g / d l^{*}$ & $n g / d l$ & cpm/liter & cpm/liter & liter/d & liters $/ d / m^{2}$ & $\mathrm{cpm} / \mathrm{ng}$ & $\mathrm{cpm} / \mathrm{ng}$ & $\mathrm{cpm} / \mathrm{ng}$ & $\mu g / d$ \\
\hline \multicolumn{13}{|l|}{ Male } \\
\hline 1 & 36.1 & 55.1 & 21.3 & 302.5 & 93,110 & 90,913 & 1,177 & 680 & 167 & 73.7 & 29.1 & 648.5 \\
\hline 2 & 35.2 & 73.1 & 26.75 & 404.7 & 110,889 & 117,640 & 925 & 446 & 156 & 49.7 & 12.6 & 676 \\
\hline 3 & 31.4 & 34.8 & 21.1 & 345.3 & 64,960 & 67,653 & 1,421 & 546 & 190.5 & 70.2 & 22.3 & 494.4 \\
\hline 4 & 32.8 & 51.5 & 27.2 & 517.5 & 52,237 & 62,898 & 1,702 & 851 & 112 & 60.7 & 15 & 877 \\
\hline Mean & & 53.6 & 24.08 & 392.5 & 80.299 & 84,776 & 1,306 & 630 & 156.4 & 63.6 & 19.7 & 673.9 \\
\hline$\pm \mathrm{SE}$ & & \pm 7.9 & \pm 1.7 & \pm 46.6 & $\pm 26,599$ & $\pm 25,096$ & \pm 166 & \pm 88 & \pm 16.4 & \pm 5.4 & \pm 3.7 & \pm 78.6 \\
\hline \multicolumn{13}{|l|}{ Female } \\
\hline 1 & 33.5 & 14.4 & 7.1 & 101.9 & 250,312 & 231,022 & 417 & 271 & 1,671 & 241 & 67 & 60.0 \\
\hline 2 & 43.4 & 12.0 & 10.4 & 162.3 & 287,043 & 270,792 & 467 & 314 & 1,102 & 295.3 & 97.8 & 56.0 \\
\hline 3 & 38.5 & 6.0 & 3.0 & 34.0 & 238,534 & 242,136 & 481 & 301 & 4,019 & 1,114 & 242 & 28.9 \\
\hline 4 & 35.4 & 6.1 & 4.3 & 109.8 & 121,763 & 114,978 & 890 & 463 & 1,812 & 557 & 181.6 & 54.5 \\
\hline 5 & 40.6 & 22.0 & 5.1 & 78.0 & 363,848 & 344,824 & 344 & 246 & 1,476 & - & 151.2 & 75.7 \\
\hline Mean & & 12.1 & 6.0 & 97 & 252,300 & 240,750 & 520 & 319 & 2,016 & 551 & 147.9 & 55 \\
\hline$\pm \mathrm{SE}$ & & \pm 3.0 & \pm 1.3 & \pm 21 & $\pm 87,868$ & $\pm 83,140$ & 96 & \pm 38 & \pm 516 & \pm 200 & \pm 30.9 & \pm 7.5 \\
\hline
\end{tabular}

* Data on infusion rates, labeled and unlabeled steroid concentrations in plasma, and calculated clearance (MCR), production (P), and specific activities after an 8-hour infusion of [ $\left.{ }^{3} \mathrm{H}\right] \mathrm{DHT}$ in men and women.

${ }^{\ddagger}$ Represents the mean of a.m.-p.m. values.

Comparison between rates determined in blood and urine. As previously reported, there are major differences in the plasma concentration of DHT, $3 \alpha$ diol, and $3 \alpha$ diolG for each sex. However, no significant urinary DHT and $3 \alpha$ diol differences between the sexes were apparent in this small series, and plasma differences between the sexes were much more marked than urine differences. In contrast with the unconjugated androgens, a large difference was present between $3 \alpha$ diolG in urine of males and females ( $106 \pm 17$ vs. $24 \pm 9 \mu \mathrm{g} / \mathrm{d}, P<0.01$ ); values did not overlap. Note that $3 \alpha$ diolG values were reported as the steroid mass only for comparison with unconjugated steroids.

As was noted in plasma, the specific activities of androgens were higher in females than males and there was a reduction in specific activity between DHT and 3 $\alpha$ diol (Fig. 2). However, in contrast, the specific activity of $3 \alpha$ diolG was higher than $3 \alpha$ diol in females.

The calculated $\mathrm{P}_{\mathrm{B}}{ }^{\mathrm{DHT}}$ and $\mathrm{P}_{\mathrm{U}}{ }^{\mathrm{DHT}}$ show important differences for each sex (Fig. 3). The DHT production rate in men was

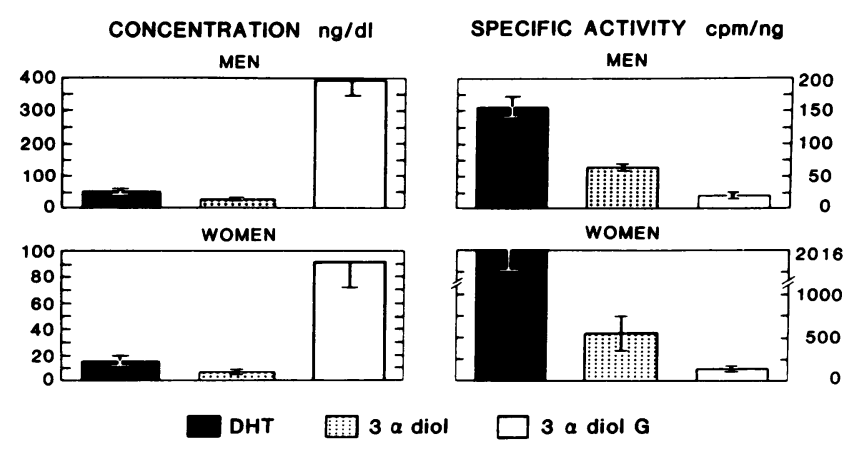

Figure 1. Concentrations of plasma DHT, $3 \alpha$ diol, and $3 \alpha$ diolG and specific activities of these androgens in plasma after an 8-h infusion of $\left.{ }^{3} \mathrm{H}\right] \mathrm{DHT}$ in normal men (top) and women (bottom). similar in most individuals and as a group between blood and urine $\left(P_{B}{ }^{\text {DHT }} 674 \pm 79 \mu \mathrm{g} / \mathrm{d}\right.$ vs. $\left.P_{U}{ }^{\text {DHT }} 788 \pm 207 \mu \mathrm{g} / \mathrm{d}, P=\mathrm{NS}\right)$. Specific activities of DHT were lower in the urine of females in each case, and there was a significant difference between $P_{B}{ }^{D H T}$ and $P_{U}{ }^{\text {DHT }}\left(P_{B}{ }^{\text {DHT }} 55 \pm 7 \mu \mathrm{g} / \mathrm{d}\right.$ vs. $\left.P_{U}{ }^{\text {DHT }} 174 \pm 55 \mu \mathrm{g} / \mathrm{d}, P<0.02\right)$. The specific activities of $3 \alpha$ diolG in plasma and urine were not significantly different in either males or females, but specific activities were much lower in men despite similar injection doses of tracer DHT.

\section{Discussion}

This study was performed on normal males and females to investigate whether the specific activities and calculated $P_{B}{ }^{D H T}$ and $P_{U}{ }^{D H T}$ were derived from the same compartment or pool. Our hypothesis was that peripherally synthesized steroid hormones might at least in part be locally metabolized and that only a fraction of total body production be reflected by blood levels or blood production rates. This concept appears intuitively valid; studies of blood and tissue sex steroid levels and formation rates of androgens in females with hirsutism and acne all indirectly support this concept $(21,22)$. Earlier studies demonstrated that the blood production of testosterone in women was only a fraction of that calculated from analysis of urinary testosterone glucuronide, which indicates that androstenedione is a testosterone prehormone in women $(23,24)$. This earlier work implied that peripheral formation of testosterone was much greater than that which entered the circulation; therefore, we have compared specific activities and calculated production rates of DHT. It was also appropriate to compare specific activities of $3 \alpha$ diol and the putative DHT product, $3 \alpha$ diolG since this metabolite appeared to more accurately reflect peripheral DHT formation than did DHT or even $3 \alpha$ diol. We did not analyze blood and urine DHT glucuronide since our previous study demonstrated 


\begin{tabular}{|c|c|c|c|c|c|c|c|c|}
\hline & \multirow{2}{*}{$\begin{array}{l}\text { Counts infused } \\
+ \text { loading dose } \times 10^{-6}\end{array}$} & \multirow[b]{2}{*}{ DHT } & \multirow[b]{2}{*}{ 3adiol } & \multirow[b]{2}{*}{ 3adiolG } & \multicolumn{3}{|c|}{ Specific activity } & \multirow[b]{2}{*}{$\mathbf{P}_{\mathrm{U}}^{\text {DHT }}$} \\
\hline & & & & & DHT & 3adiol & 3adiolG & \\
\hline & & $n g / 24 h$ & $n g / 24 h$ & $\mu g / 24 h$ & $\mathrm{cpm} / \mathrm{ng}$ & $c p m / n g$ & $c p m / n g$ & $\mu g / d$ \\
\hline \multicolumn{9}{|l|}{ Male } \\
\hline 1 & 38.09 & 82.6 & 185 & 79.2 & 53.4 & 4.9 & 22.8 & 713 \\
\hline 2 & 37.14 & 184.8 & 282 & 147.5 & 26.8 & 5.9 & 8.9 & 1,385 \\
\hline 3 & 33.13 & 93.9 & 187 & 120.9 & 76.4 & 31.3 & 16.6 & 433 \\
\hline 4 & 34.45 & 98.2 & 161 & 75.8 & 55.2 & 14.1 & 22.3 & 624 \\
\hline Mean & & 114.9 & 203.7 & 105.9 & 52.9 & 14.1 & 17.6 & 788 \\
\hline$\pm \mathrm{SE}$ & & \pm 23.5 & \pm 26.7 & \pm 17.3 & \pm 10.16 & \pm 6.1 & \pm 3.2 & \pm 207 \\
\hline \multicolumn{9}{|l|}{ Female } \\
\hline 1 & 36.5 & 40.1 & 30.5 & 18.7 & 361 & 36 & 70 & 101 \\
\hline 2 & 45.84 & 205.2 & 413.8 & 58.5 & 119.5 & 30.4 & 35 & 383 \\
\hline 3 & 40.65 & 26.2 & 42.9 & 7 & 302.2 & 14.7 & 218.6 & 134.5 \\
\hline 4 & 37.30 & 63.6 & 122.3 & 26 & 509.4 & 34.6 & 112 & 73.2 \\
\hline 5 & 42.82 & 39 & - & 10.4 & 242 & - & 131.8 & 177 \\
\hline Mean & & 74.8 & 152 & 24.1 & 306.8 & 28 & 113.5 & 173.7 \\
\hline$\pm \mathrm{SE}$ & & \pm 33.2 & \pm 89 & \pm 9.2 & \pm 55 & \pm 4.8 & \pm 31.2 & \pm 55.2 \\
\hline
\end{tabular}

* Data on infusion rates and loading doses of $\left[{ }^{3} \mathrm{H}\right] \mathrm{DHT}$, excretion rates of DHT, $3 \alpha$ DIOL, and $3 \alpha$ DIOLG as well as specific activities of these steroids and the calculated production rates from analysis of urinary DHT in men and women.

that testosterone is its major precursor (19). Sampling at other sites in vivo (e.g., muscle or fat) is not practical since differences across most organs and tissues should be a low order. We assume that major differences in specific activities between urine and blood of these steroids represented the contribution of the kidney and associated sexual tissue, and there is evidence that the kidney is an active site of DHT formation (25-27).

Plasma values of DHT, $3 \alpha$ diol, and $3 \alpha$ diolG in our study groups were very similar to those reported from larger control series. Whereas our mean a.m. and p.m. values may be somewhat different from those derived from integrating values throughout the day, our pilot studies indicate that only minor circadian variation occurred. Previous studies and additional proof of purity performed in the present project all provide evidence that a steady state of DHT, $3 \alpha$ diol, and $3 \alpha$ diolG in blood is achieved during the labeled DHT infusion, and that the steroids isolated by repetitive column and paper chromatography are radiochemically pure.

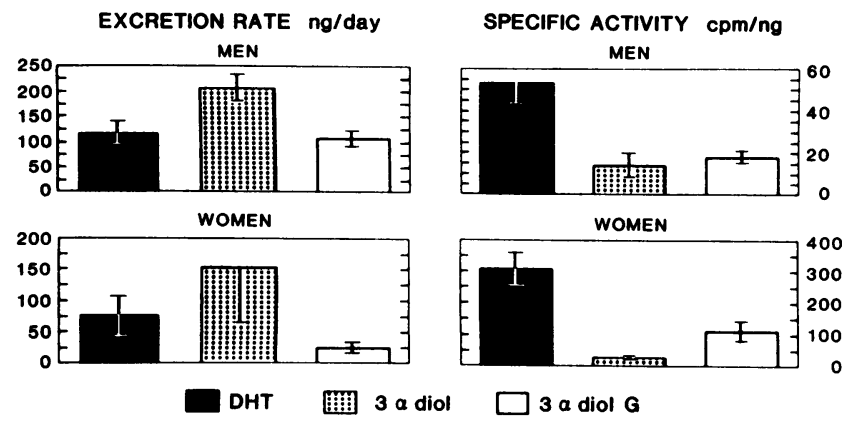

Figure 2. Urinary excretion rate of DHT, $3 \alpha$ diol, and $3 \alpha$ diolG and specific activities of these androgens after infusion of $\left[{ }^{3} \mathrm{H}\right] \mathrm{DHT}$ in both men and women.
The metabolic clearance and production rates given in liters per day or corrected for surface area of DHT are $\sim 50 \%$ higher in both men and women than those previously reported by us and others $(3,4)$. This may be the result of our small numbers or reflect the much longer period of infusion in the supine position as compared with previously reported 1-2-h procedures. This is also reflected in the $P_{B}{ }^{D H T}$ of $674 \pm 79$ and $55 \pm 8 \mu \mathrm{g} / \mathrm{d}$ in men and women in our present study. We believe these values are correct and cite the minor differences in DHT radioactivity and specific activities that were observed in 6- and 8-h blood samples as evidence for steady state conditions. However, further studies will be necessary to determine whether steady state conditions were completely attained in the earlier literature.

The progressive reduction in specific activities between infused DHT, and 3adiol and its conjugate in plasma is compatible with the biosynthetic scheme DHT $\leftrightharpoons 3 \alpha$ diol $\rightarrow 3 \alpha$ diolG. However, a progressive reduction also suggests the role of other precursors, and a pathway to $3 \alpha$ diolG not exclusively via DHT and

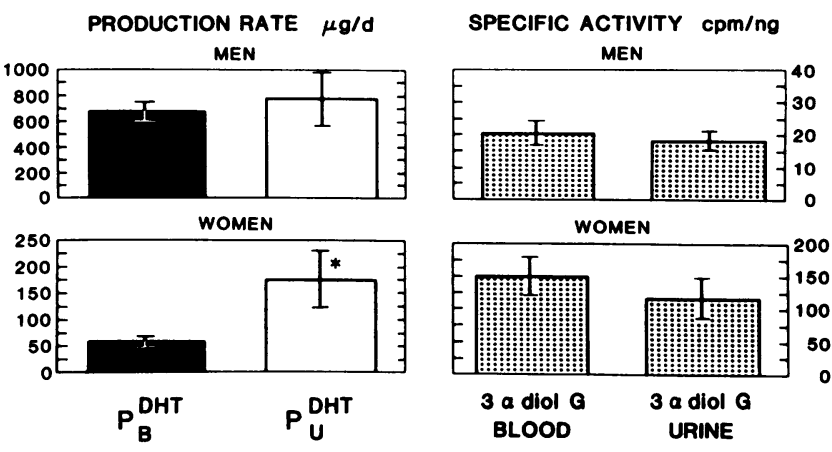

Figure 3. Daily $\mathrm{P}_{\mathrm{B}}{ }^{\mathrm{DHT}}$ and $\mathrm{P}_{\mathrm{U}}{ }^{\mathrm{DHT}}$ calculated and specific activities of $3 \alpha$ diolG in blood and urine from normal men and women. 
$3 \alpha$ diol. We have recently demonstrated that androstenedione is a precursor of $3 \alpha$ diolG in normal and hirsute women (28), and there may be other $\mathrm{C} 19$ precursors.

This study presents for the first time data on the urinary excretion of unconjugated DHT and $3 \alpha$ diol, and compares $3 \alpha$ diolG simultaneously both in blood and urine. Unexpectedly, there was about twice as much $3 \alpha$ diol as DHT in urine in both sexes. Only small amounts of these androgens were not bound to sex hormone binding globulin in plasma and were able to be filtered and excreted by the kidney. Perhaps the larger amount of $3 \alpha$ diol was a reflection of somewhat less binding of sex hormone binding globulin than DHT, but the possibility of local formation and excretion by renal tissue must also be considered. This latter possibility was strengthened by the lower specific activity noted in each subject for $3 \alpha$ diol vs. DHT. There were also minimal excretion rate differences for each sex as compared

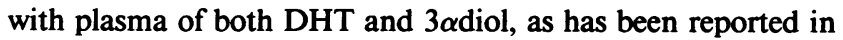
vitro in animals (25).

In both sexes, the specific activity of $3 \alpha$ diolG between blood and urine was not significantly different. The urinary $3 \alpha$ diolGmass values are similar to those reported by Wright et al. (28) and others $(29,30)$. Between the sexes, there were major differences in the excretion rates of $3 \alpha$ diolG $(106 \pm 17$ vs. $27.6 \pm 11$ $\mu \mathrm{g} / \mathrm{d}, P<0.01)$ as compared with DHT and $3 \alpha$ diol. The specific activity of $3 \alpha$ diol in urine of females was higher than $3 \alpha$ diolG, which suggests that they arose in part from different sites in the kidney and that $3 \alpha$ diol can be excreted without being conjugated.

The most important observation of the study relates to the differences in calculated $\mathrm{P}_{\mathrm{B}}{ }^{\mathrm{DHT}}$ and those determined from analysis of DHT in urine. $\mathrm{P}_{\mathrm{B}}{ }^{\mathrm{DHT}}$ can be determined by comparison of injected and steady state specific activities and this formula can be converted into the product of the plasma concentration of the substance and its MCR. Similarly, in urine the ratio of specific activities can be simplified into the total dose of labeled steroid that was infused or injected and the specific activities. When these calculations were made in previous studies after injecting $\left[{ }^{3} \mathrm{H}\right]$ testosterone, the blood and urinary determinations were very similar in men, which indicates that blood testosterone and urinary testosterone glucuronide were derived from a single source or compartment. However, in women the urinary metabolite production rate was four to five times that of blood. Testosterone in urine was not a unique metabolite of secreted testosterone, but rather was derived from peripheral formation from androstenedione and other precursors.

A similar conclusion can now be made for DHT. In men, $P_{B}{ }^{D H T}$ and $P_{U}{ }^{D H T}$ were comparable $(674 \pm 79$ vs. $786 \pm 207 \mu \mathrm{g} / \mathrm{d}$, $P=\mathrm{NS}$ ). However, in women there was a major difference between the calculated production rates that were determined from the two sites ( $55 \pm 8$ vs. $174 \pm 55 \mu \mathrm{g} / \mathrm{d}, P<0.02)$. The differences in production rates were easier to visualize than the specific activities since, in blood, it was derived from an 8-h infusion, which would have had to be corrected for a 24-h infusion to make direct comparisons.

We interpret this data to be analogous to the earlier discovery on sources and sites of testosterone formation in women. A significant fraction of DHT formed in peripheral tissues must be further metabolized locally. In our study, we were probably seeing only differences generated by urogenital tissue, primarily the kidney. The differences were brought out in the female, where $P_{B}{ }^{\text {DHT }}$ was low and any renal synthesis of DHT, $3 \alpha$ diol, and $3 \alpha$ diolG could more easily be detected. Other secreted C19 ste- roids such as androstenedione, 5 -androstene- $3 \alpha, 17 \beta$-diol, or dehydroisoandrosterone could also serve as precursors.

In men, the specific activity of $3 \alpha$ diol and its conjugate was similar, probably because the major $\mathrm{C} 19$ androgen is testosterone. However, in women the specific activities of $3 \alpha$ diol and $3 \alpha$ diolG were quite different, which suggests that $3 \alpha$ diolG was synthesized in sites different from $3 \alpha$ diol or that blood $3 \alpha$ diol was not in equilibrium with $3 \alpha$ diol in sites where $3 \alpha$ diolG was synthesized. Urinary $3 \alpha$ diolG appeared to arise from the same compartment as blood $3 \alpha$ diolG, especially in the male, although we have recently reported that only a fraction of the blood production of this conjugate appears in urine, and thus another site of excretion or additional degradative steps must be present.

A practical outgrowth of this study is that it provides more direct proof that peripherally formed androgens are locally metabolized. Blood levels of these hormones may be an inadequate measure of total or peripheral formation and, as discussed, this appears to be the case for many disorders of androgen (and estrogen) formation and action. Markers of peripheral steroid production such as certain steroid conjugates may be of considerable value in the evaluation of disorders of peripheral formation.

\section{Acknowledgment}

Dr. V. Toscano was the recipient of North Atlantic Treaty Organization Senior Fellowship (217.16) that was awarded by the Consiglio Nazionale Delle Ricerchi Rome, Italy. This work was supported by National Institutes of Health grant AM 13710.

\section{References}

1. Baulieu, E. E., I. Lasnitzki, and P. Robel. 1968. Metabolism of testosterone and action of metabolites on prostate gland grown in organ culture. Nature (Lond.). 219:1155-1156.

2. Wilson, J. D. 1972. Recent studies on the mechanism of action of testosterone. N. Engl. J. Med. 287:1284-1291.

3. Mahoudeau, J. A., C. W. Bardin, and M. B. Lipsett. 1971. The metabolic clearance rate and origin of plasma dihydrotestosterone in man and its conversion to the $5 \alpha$ androstanediols. J. Clin. Invest. 50: 1338-1344.

4. Ito, T., and R. Horton. 1971. The source of plasma dihydrotestosterone in man. J. Clin. Invest. 50:1621-1627.

5. Kinouchi, T., and R. Horton. 1974. $3 \alpha$ androstanediol kinetics in man. J. Clin. Invest. 54:646-653.

6. Mauvals-Jarvis, P., G. Charransol, and F. Bobaus Masson. 1973. Simultaneous determination of urine androstanediol and testosterone as an evaluation of human androgenicity. J. Clin. Endocrinol. \& Metab. $36: 452-459$.

7. Horton, R., D. Hawks, and R. Lobo. 1982. $3 \alpha, 17 \beta$ androstanediol glucuronide in plasma. J. Clin. Invest. 69:1203-1209.

8. Chung, L., and D. Coffey. 1977. Androgen glucuronides: direct formation in rat accessory sex organs. Steroids. 30:223-243.

9. Ishimaru, T., A. Edmiston, L. Pages, and R. Horton. 1978. Splanchnic extraction and conversion of testosterone and dihydrotestosterone in man. J. Clin. Endocrinol. \& Metab. 46:528-533.

10. Morimoto, I., A. Edmiston, D. Hawks, and R. Horton. 1981. Studies on the origin of androstanediol and androstanediol glucuronide in young and elderly men. J. Clin. Endocrinol. \& Metab. 52:772-778.

11. Sciarra, F., V. Toscano, D. Casilli, M. V. Adamo, M. Maroder, and C. Conti. 1984. Three androstanediol concentrations in ovarian and adrenal blood effluents in normal and hirsute women. VII International Congress of Endocrinology. Excerpta Medica, Amsterdam/Oxford/ Princeton. 1345. (Abst.)

12. Toscano, V., F. Sciarra, M. W. Adamo, E. Petrangell, S. Foli, S. 
Caiola, and C. Conti. 1982. Is $3 \alpha$ androstanediol a marker of peripheral hirsutism? Acta Endocrinol. 99:314-319.

13. Lookingbill, D. P., R. Horton, L. Demers, N. Egan, J. G. Marks, and R. J. Santen. 1983. Tissue production of androgens in women with acne. J. Am. Acad. Dermatol. 12:481-487.

14. Sanson, G., and R. Reisner. 1971. Differential rates of conversion of testosterone to DHT in acne and in human skin. J. Invest. Dermatol. 56:366-372.

15. Voigt, W., E. Fernandez, and S. Hsla. 1970. Transformation of testosterone into DHT by human skin. J. Biol. Chem. 245:5594-5599.

16. Imperato-McGinley, J., R. E. Peterson, T. Gautier, G. Cooper, R. Danner, A. Arthur, P. J. Morris, W. J. Sweeney, and C. Shackleton. 1982. Hormonal evaluation of a large kindred with complete androgen insensitivity: evidence for secondary $5 \alpha$ reductase deficiency. J. Clin. Endocrinol. \& Metab. 54:931-941.

17. Horton, R. 1984. Markers of peripheral androgen production. In Sexual Differentiation. M. Serio and L. Martini, editors. Academic Press, Inc., New York. 261-274.

18. Greep, N., M. Hoopes, and R. Horton. 1986. Androstanediol glucuronide plasma clearance and production rates in normal and hirsute women. J. Clin. Endocrinol. \& Metab. 62:22-27.

19. Moghissi, E., F. Ablan, and R. Horton. 1984. Origin of plasma androstanediol glucuronide in men. J. Clin. Endocrinol. \& Metab. 59: 417-421.

20. Horton, R., D. Endres, and M. Galmarini. 1984. Ideal conditions for hydrolysis of androstanediol $3 \alpha, 17 \beta$-diol glucuronide in plasma. $J$. Clin. Endocrinol. \& Metab. 59:1027.
21. Mauvais-Jarvis, P., F. Kuttenn, and I. Mowszowicz. 1981. Hirsutism. Monogr. Endocrinology. 19:1-110.

22. Toscano, V. 1986. Dihydrotestosterone metabolism. Clin. Endocrinol. Metab. 15:279-292.

23. Horton, R., J. Shinsako, and P. H. Forsham. 1965. Testosterone production and metabolic clearance rates with volumes of distribution in normal adult men and women. Acta Endocrinol. 48:446-451.

24. Horton, R., and J. F. Tait. 1966. Androstenedione production and interconversion rates measured in peripheral blood and studies on the possible site of its conversion to testosterone. J. Clin. Invest. 45:301.

25. Bullock, L. P., and C. W. Bardin. 1975. The vivo androgen retention in mouse kidney. Steroids. 25:107-119.

26. Mainwaring, W. I. P., and F. R. Mangan. 1973. A study of the androgen receptors in a variety of androgen-sensitive tissues. $J$. Endocrinol. 59:121-139.

27. Bruchovsky, N., and J. D. Wilson. 1968. The conversion of testosterone to $5 \alpha$ androstan-17 $\beta$-ol-3 one by rat prostate in vivo and in vitro. J. Biol. Chem. 243:2012-2021.

28. Greep, N., M. Hoopes, and R. Horton. 1985. Evidence for a role of androstenedione as precursor of plasma DHT and androstanediol glucuronide in normal and hirsute women. Prog. Endocr. Soc. 67:66 (Abstr.)

29. Wright, F., I. Mowszowicz, and P. Mauvais-Jarvis. 1978. Urinary $5 \alpha$-androstane-3 $\alpha, 17 \beta$-diol radioimmunoassay: a new clinical evaluation. J. Clin. Endocrinol. \& Metab. 47:850-854.

30. Deslypere, J-P, A. Sayed, V. Punjabi, L. Verdonk, and A. Vermeulen. 1982. Plasma 5 androstane- $3 \alpha, 17 \beta$-diol and urinary 5 androstane-3 $\alpha, 17 \beta$-diol glucuronide parameters of peripheral androgen action: a comparative study. J. Clin. Endocrinol. \& Metab. 54:386-391. 